\title{
Long-term simulation of lead concentrations in agricultural soils in relation to human adverse health effects
}

\author{
Thomas Schupp ${ }^{1}$ (D) Georg Damm ${ }^{2} \cdot$ Heidi Foth $^{3} \cdot$ Alexius Freyberger $^{4} \cdot$ Thomas Gebel $^{5} \cdot$ Ursula Gundert-Remy $^{6}$. \\ Jan G. Hengstler ${ }^{7}$. Aswin Mangerich ${ }^{8} \cdot$ Falko Partosch $^{9} \cdot$ Claudia Röhl $^{10} \cdot$ Klaus-Michael Wollin $^{11}$
}

Received: 17 March 2020 / Accepted: 22 April 2020 / Published online: 5 May 2020

(c) The Author(s) 2020

\begin{abstract}
Lead $(\mathrm{Pb})$ exposure of consumers and the environment has been reduced over the past decades. Despite all measures taken, immission of $\mathrm{Pb}$ onto agricultural soils still occurs, with fertilizer application, lead shot from hunting activities, and $\mathrm{Pb}$ from air deposition representing major sources. Little is known about the intermediate and long-term consequences of these emissions. To gain more insight, we established a mathematical model that considers input from fertilizer, ammunition, deposition from air, uptake of $\mathrm{Pb}$ by crops, and wash-out to simulate the resulting $\mathrm{Pb}$ concentrations in soil over extended periods. In a further step, human oral exposure by crop-based food was simulated and blood concentrations were derived to estimate the margin of exposure to $\mathrm{Pb}$-induced toxic effects. Simulating current farming scenarios, a new equilibrium concentration of $\mathrm{Pb}$ in soil would be established after several centuries. Developmental neurotoxicity represents the most critical toxicological effect of $\mathrm{Pb}$ for humans. According to our model, a Pb concentration of $\sim 5 \mathrm{mg} / \mathrm{kg}$ in agricultural soil leads to an intake of approximately $10 \mu \mathrm{g} \mathrm{Pb}$ per person per day by the consumption of agricultural products, the dose corresponding to the tolerable daily intake (TDI). Therefore, $5 \mathrm{mg} \mathrm{Pb} / \mathrm{kg}$ represents a critical concentration in soil that should not be exceeded. Starting with a soil concentration of $0.1 \mathrm{mg} / \mathrm{kg}$, the current control level for crop fields, our simulation predicts periods of $\sim 50$ and $\sim 175$ years for two $\mathrm{Pb}$ immission scenarios for mass of $\mathrm{Pb}$ per area and year [scenario 1: $\sim 400 \mathrm{~g}$ $\mathrm{Pb} /($ ha $\times \mathrm{a}$ ); scenario 2: $\sim 175 \mathrm{~g} \mathrm{~Pb} /($ ha $\times \mathrm{a})]$, until the critical concentration of $\sim 5 \mathrm{mg} / \mathrm{kg} \mathrm{Pb}$ in soil would be reached. The two scenarios, which differ in their $\mathrm{Pb}$ input via fertilizer, represent relatively high but not unrealistic $\mathrm{Pb}$ immissions. From these scenarios, we calculated that the annual deposition of $\mathrm{Pb}$ onto soil should remain below $\sim 100 \mathrm{~g} /(\mathrm{ha} \times \mathrm{a})$ in order not to exceed the critical soil level of $5 \mathrm{mg} / \mathrm{kg}$. We propose as efficient measures to reduce $\mathrm{Pb}$ input into agricultural soil to lower the $\mathrm{Pb}$ content of compost and to use alternatives to $\mathrm{Pb}$ ammunition for hunting.
\end{abstract}

Keywords Lead $\cdot \mathrm{Pb} \cdot$ Hunting $\cdot$ Gunshot $\cdot$ Fertilizer $\cdot$ Soil contamination $\cdot$ Food contamination $\cdot$ Consumer risk

\section{Introduction}

Lead $(\mathrm{Pb})$ and $\mathrm{Pb}$ compounds have been used since ancient times, e.g., in water pipes, roofing, as pigments in paints (carbonate, sulfate, chromate), in ammunition, shielding material against radiation and as weighting material. $\mathrm{Pb}$ is highly toxic for humans and still raises major concerns due to its presence in food (WHO/JECFA 2011). Over the last decades,

Electronic supplementary material The online version of this article (https://doi.org/10.1007/s00204-020-02762-x) contains supplementary material, which is available to authorized users.

Thomas Schupp

thomas.schupp@fh-muenster.de

Extended author information available on the last page of the article measures were undertaken to reduce $\mathrm{Pb}$ exposure. For example, leaded gasoline was phased out during the 1980s in many industrialized countries. As a result, blood $\mathrm{Pb}$ concentrations of the general population decreased (Wietlisbach et al. 1995; Pirkle et al. 1994). Other applications of $\mathrm{Pb}$, e.g., in solders for drinking water pipe plumbing, for roofing, in pigments in paints, in toys, and in ceramics for food contact, were increasingly regulated or banned in the European Union (EU). Use in paint has been restricted in the EU (see Regulation [EU] No. 1907/2006, Annex XVII), but painted material containing $\mathrm{Pb}$ pigments is still in use and may lead to intoxications (O'Connor et al. 2018). All these regulatory activities have resulted in reduced $\mathrm{Pb}$ immissions into the environment and reduced $\mathrm{Pb}$ burden in environmental media. From 1990 to 2015, declining background deposition of $\mathrm{Pb}$ could be 
demonstrated by Pb-monitoring in earthworms (LUBW 2006) and in moss species (Schröder and Nickel 2019). Human biomonitoring reference values for $\mathrm{Pb}$ in blood of children in Germany declined from $60 \mu \mathrm{g} / \mathrm{L}$ in 1992 to $50 \mu \mathrm{g} / \mathrm{L}$ in 2003, and finally, $36.3 \mu \mathrm{g} / \mathrm{L}$ in 2009 (Umweltbundesamt 1998, $2005,2009)$. Permitted immission and concentration in soil for different contaminants are regulated on national levels. For example, the German Federal Soil Protection and Contaminated Sites Ordinance (Bundesbodenschutz-Verordnung) addresses $\mathrm{Pb}$ with control levels (Prïfwert) of $400 \mathrm{mg} / \mathrm{kg}$ for residential areas, $200 \mathrm{mg} / \mathrm{kg}$ for children's playgrounds, $1200 \mathrm{mg} / \mathrm{kg}$ for meadows, and $0.1 \mathrm{mg} / \mathrm{kg}$ for crop-fields. If the control level is exceeded, further measures have to be taken to identify and manage potential risks. Precautionary levels named in this ordinance define concentrations which indicate a risk if exceeded; for $\mathrm{Pb}$, these levels are 40,70 and $100 \mathrm{mg}$ / $\mathrm{kg}$ for sand-, silt- and clay-soil, respectively. The annual emission of $\mathrm{Pb}$ on soil should not exceed $400 \mathrm{~g} / \mathrm{ha}$ (BMJV 2017). Despite all measures taken to address and reduce emissions of, and exposure to $\mathrm{Pb}$, the European Food Safety Administration (EFSA) reports oral $\mathrm{Pb}$ exposure via food that deserve further attention (EFSA 2010, 2012).

Little is known if current immission of $\mathrm{Pb}$ onto farmland is high enough to cause an increase of $\mathrm{Pb}$ concentrations over longer periods. To answer this question, we established a mathematical model that allows long-term simulations of $\mathrm{Pb}$ concentrations in soil for specific input scenarios. We addressed the question what level of $\mathrm{Pb}$ input would lead to concentrations where adverse effects for humans can no longer be excluded.

\section{Methods}

\section{The model}

Figure 1 depicts schematically the modeling of the scenario to estimate potential future trends for oral $\mathrm{Pb}$ exposure via crop intake. In brief, the input into soil was treated as firstorder reaction kinetics, and the $\mathrm{Pb}$ uptake by plants was calculated by distribution models. An equipartitioning of $\mathrm{Pb}$ in the plant tissue was assumed and leads to calculated $\mathrm{Pb}$ contents in edible parts of the plants. Daily crop intake data were used to estimate the daily oral $\mathrm{Pb}$ exposure from crops. The following stepwise approach was applied:

Step 1: For a hypothetical agricultural field, the initial concentrations of $\mathrm{Pb}$ were set to the control levels of the German Soil Protection Act and its subsequent Ordinances, which are $0.1 \mathrm{mg} / \mathrm{kg}$ for crop fields (soil scenario 1), or $70 \mathrm{mg} / \mathrm{kg}$, which is the precautionary level for silt soils (soil scenario 2); silt soils are preferred, fertile farmlands. The simulated input of $\mathrm{Pb}$ per time and surface area can occur as deposition of rural background levels of $\mathrm{Pb}$ in air, via $\mathrm{Pb}$ contaminated fertilizer and by deposition of gunshot.

Step 2: For the assessment of $\mathrm{Pb}$ balance in soil, the soil content was calculated as a relation between a static, continuous input and the output by wash-out and plant uptake (plant remediation).

Step 3: The uptake of $\mathrm{Pb}$ by plants was calculated depending on soil concentrations for different types of crops. The calculation was based on published data for $\mathrm{Pb}$ uptake and crop yield per surface area.

Step 4: Oral $\mathrm{Pb}$ exposure via crops was estimated based on the average vegetarian dietary habits for adults, or based on the recommended children food basket for children of $20 \mathrm{~kg}$ body weight (b.w.), multiplied with the calculated $\mathrm{Pb}$ contents in the different crops from Step 3. It is assumed that cooking does not reduce the $\mathrm{Pb}$ load in plant food.

Step 5: The most sensitive effects for $\mathrm{Pb}$ toxicity were considered, and associated $\mathrm{Pb}$ blood levels were matched against oral exposure as derived in Step 4.

\section{Lead input}

Several possible sources of $\mathrm{Pb}$ input into soil were considered. Dust and aerosols may contain $\mathrm{Pb}$ due to natural,
Fig. 1 Model for human oral exposure via vegetable products and crops by dispersive deposition of $\mathrm{Pb}$ on agricultural soil

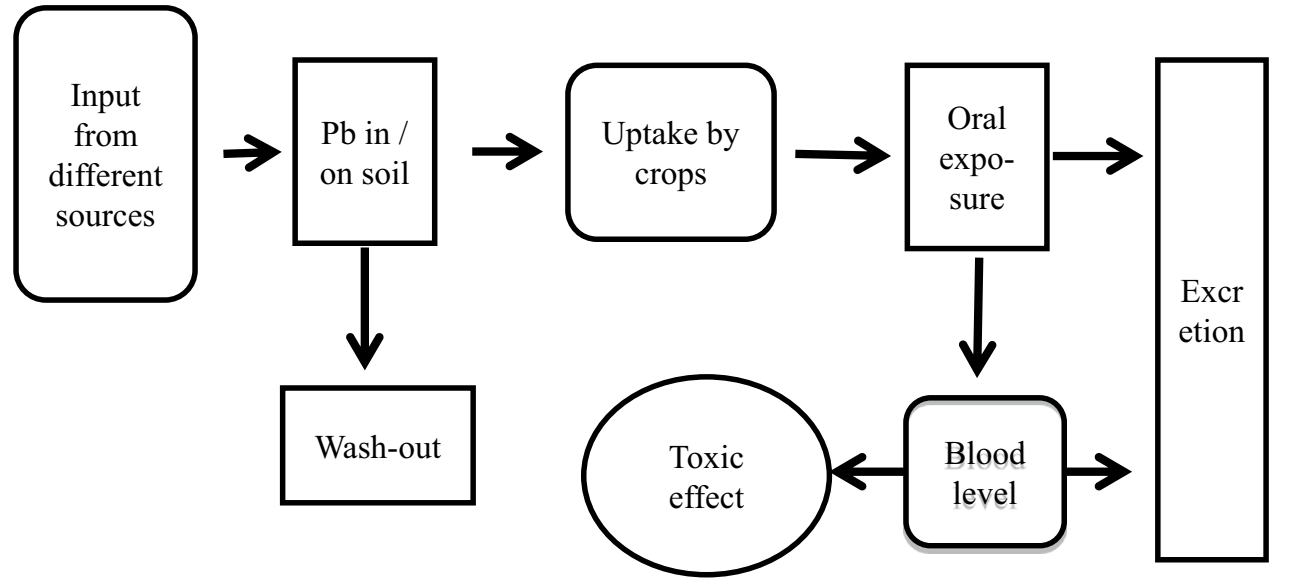


geological presence and/or due to industrial activities; wet and dry deposition of this material is termed as "immission" in this document. Background deposition of $\mathrm{Pb}$ in rural areas of Germany is in a range of $8-14 \mathrm{~g} /($ ha $\times a$ ) (Schaap et al. 2018), and the median of $11 \mathrm{~g} /($ ha $\times a$ ) was used for the calculations in this report.

Hunting with gunshot is the second contributor for $\mathrm{Pb}$ input into soil modeled in this document. In the EU, $14,000 \mathrm{t} / \mathrm{a} \mathrm{Pb}$ are dispersed annually as gunshot in hunting areas; another 10,000-20,000 t/a are expected to be deposited on shooting ranges (ECHA 2018b). Gunshot is typically used for game that is hunted on fields and meadows. If the 14,000 annual tons gunshot estimated by ECHA are dispersed over the agricultural surface area of the EU which is 174 million hectare (EC 2017), this would result in an annual load of $80 \mathrm{~g} /($ ha $\times a)$.

The use of fertilizer is the third identified source of $\mathrm{Pb}$ input into soil. For Germany, a detailed analysis of fertilizer use was performed by Knappe et al. (2008); the authors divided conventional farming into four scenarios:
a. Use of cattle manure and mineral fertilizer.
b. Use of compost and mineral fertilizer.
c. Use of sewage sludge and mineral fertilizer.
d. Exclusive use of mineral fertilizer.

Data for annual $\mathrm{Pb}$ input on soil via fertilizer in dependence on the farming scenario are presented in Table 1.

\section{Lead uptake by crop plants}

For calculation of the $\mathrm{Pb}$ balance in soil, knowledge of the extent of $\mathrm{Pb}$ uptake by plants is required. Extractable $\mathrm{Pb}$ in soil is known to correlate with $\mathrm{Pb}$ in plant tissue, and a linear relation between $\mathrm{Pb}$ in soil and $\mathrm{Pb}$ in plants has been reported (Dudka et al. 1996; Attanayake et al. 2014):

barley grain: $[\mathrm{Pb}]_{\text {plant }}=0.0003 \times[\mathrm{Pb}]_{\text {soil }}$.

leaf vegetable: $[\mathrm{Pb}]_{\text {plant }}=0.01 \times[\mathrm{Pb}]_{\text {soil }}$.

Table $1 \mathrm{~Pb}$ input via fertilizer in dependence on farming category according to Knappe et al. (2008)

\begin{tabular}{lcc}
\hline Farming Scenario & \multicolumn{2}{c}{$\mathrm{Pb}[\mathrm{g} /(\mathrm{ha} \times \mathrm{a})]$} \\
\cline { 2 - 3 } & Median & 90 -Percentile \\
\hline $\mathrm{A}$ & 7.5 & 9.4 \\
$\mathrm{~B}$ & 313.0 & 314.6 \\
$\mathrm{C}$ & 69.5 & 80.7 \\
$\mathrm{D}$ & 6.2 & 7.8 \\
\hline
\end{tabular}

potato tuber, peeled: $[\mathrm{Pb}]_{\text {plant }}=0.003 \times[\mathrm{Pb}]_{\text {soil }}$.

other vegetables: $[\mathrm{Pb}]_{\text {plant }}=0.0008 \times[\mathrm{Pb}]_{\text {soil }}$.

For $\mathrm{Pb}$ removal from soil, only edible parts of plants were taken into account, as the other parts of the plants are assumed as being left on the soil. The removal of $\mathrm{Pb}$ from soil by plants is not only solely dependent on the uptake factor of the different plant species, but also a function of the surface density of the plant species, expressed as $\mathrm{kg}$ biomass per $\mathrm{m}^{2}$ (yield, $Y$ ), and its share between all other plants on the surface. For our simulations, we assume that the plant species seeded on farmland are selected in such a way that the plant food demand for an adult vegetarian is matched. For example, Table 2 shows daily food intake (DI) for adult vegetarians, as listed by EFSA (2010; see Table 21) for such crops for which plant uptake factors from soil are available. The corresponding required surface of farm or gardening land to supply the daily amount of the respective plant is calculated, and the sum of all modeled plant species covering this land is set to $100 \%$ (or factor 1.0). For balancing $\mathrm{Pb}$ per $\mathrm{m}^{2}$ land, plant uptake is a sink for $\mathrm{Pb}$. As different plant species have different $\mathrm{Pb}$ uptake capabilities, the average agricultural soil surface coverage was assumed to be $67.7 \%$ for cereals, $3.6 \%$ for potatoes, $20.3 \%$ for leaf vegetables and $8.4 \%$ for other vegetables (UK GOV 2018).

As illustrated in Table 4, an adult vegetarian consumes $0.283 \mathrm{~kg}$ cereals per day. As the annual harvest (yield, $Y$ ) for cereals is $0.8 \mathrm{~kg} /\left(\mathrm{m}^{2} \times a\right), 0.354 \mathrm{~m}^{2}$ are required for the daily demand (Table 3 ). With respect to the area required for the other crops listed in Table 3, these 0.354 $\mathrm{m}^{2}$ make up $67.7 \%$ of the required farmland to satisfy the daily demand. This results in a surface weighting factor for cereals of $\mathrm{P}=0.677$.

\section{Wash-out of lead in soil}

$\mathrm{Pb}$ in soil may be washed out by irrigating water. The wash-out is the sum of infiltration and run-off, as soluble $\mathrm{Pb}$ compounds may leave the soil layer and are no longer available for plant uptake.

Table 2 Median annual $\mathrm{Pb}$ input by air deposition, gunshot and fertilizer in dependence on farming category according to Knappe et al. (2008)

\begin{tabular}{lcc}
\hline Farming & \multicolumn{2}{l}{$\mathrm{Pb}$ input (IN) } \\
\cline { 2 - 3 } & $\mathrm{mg} / \mathrm{m}^{2}$ & $\mathrm{mg} / \mathrm{kg}$ \\
\hline $\mathrm{A}$ & 9.85 & 0.029 \\
$\mathrm{~B}$ & 40.4 & 0.119 \\
$\mathrm{C}$ & 16.1 & 0.047 \\
$\mathrm{D}$ & 9.9 & 0.029 \\
\hline
\end{tabular}


Rooney et al. (2007) investigated the correlation of Pb solubility in agricultural soil pore water with the soil $\mathrm{pH}$. The soils were spiked with lead shot. At $\mathrm{pH}$ values of 6.9 and 5.7, the concentration of $\mathrm{Pb}$ in soil water reached values of approximately 0.5 and $2.0 \mathrm{mg} / \mathrm{L}$, respectively. The field measurements published by Hawkins et al. (1995) were used to estimate the losses of $\mathrm{Pb}$ in soil due to wash-out (WO); here, WO is the sum of leaching and wash-off. Leaching and wash-off resulted in an annual loss of approximately $0.2 \%$ of the $\mathrm{Pb}$ in soil, which is equivalent to a rate constant of $2.0 \times 10^{-3} \cdot a^{-1}$.

$\mathrm{WO}=2.0 \times 10^{-3} \times[\mathrm{Pb}]_{\text {soil }}[\mathrm{mg} /(\mathrm{kg} \times \mathrm{a})]$.

\section{Lead balance in soil}

For the uptake by plants, only those parts which serve as food were modeled since the other parts would most likely end up as fertilizer, i.e., $\mathrm{Pb}$ remains in the soil matrix. For removal from farmland, only uptake in edible parts were modeled. The total removal per surface area and time is dependent on the plant type (i), its individual plant uptake factors $\left(\mathrm{UF}_{\mathrm{i}}\right)$, its prevalence per surface area $\left(P_{\mathrm{i}}\right.$, between 0 and 1$)$ and its yield per time $\left(Y_{\mathrm{i}}\right)$. For the balance of $\mathrm{Pb}$ in soil per $\mathrm{m}^{2}$, the following algorithm was used:

$\mathrm{d}[\mathrm{Pb}]_{\text {soil }} / \mathrm{dt}=\mathrm{IN}-\left\{\mathrm{WO}+\sum_{i}(\mathrm{UF} \times P \times Y)_{\mathrm{i}}\right\} \times[\mathrm{Pb}]_{\text {soil }}$.

where $\mathrm{IN}$ is the input of $\mathrm{Pb}$ on soil per area and time. With data presented in Table 3, the last term in Eq. (6) can be calculated as

$$
\begin{aligned}
\sum_{i}\{\mathrm{UF} \times P \times Y\} i= & 3 \times 10^{-4} \times 0.8 \times 0.677+10^{-2} \\
& \times 5.0 \times 0.036+3 \times 10^{-3} \times 3.0 \\
& \times 0.203+8 \times 10^{-4} \times 3.3 \times 0.203 \\
& \times 0.084=4.01 \times 10^{-3} \mathrm{a}^{-1} .
\end{aligned}
$$

Table 3 Crop yield $\left[Y ; \mathrm{kg} /\left(\mathrm{m}^{2} \times \mathrm{a}\right)\right], \mathrm{Pb}$ uptake factor (UF) and soil surface $\left(\mathrm{m}^{2}\right)$ required to supply plant food for the daily intake for an adult vegetarian (EFSA 2010), and surface weighting factor $P$ $\left(P_{i}=\mathrm{m}_{i}^{2} / \sum \mathrm{m}_{i}^{2}\right)$

\begin{tabular}{lllll}
\hline Species & UF & $Y$ & $\mathrm{~m}^{2}$ & $P$ \\
\hline Cereals & $3.0 \mathrm{E}-04_{\text {soil }}^{\mathrm{a}}$ & $0.8^{\mathrm{c}}$ & 0.354 & 0.677 \\
Potatoes & $1.0 \mathrm{E}-02^{\mathrm{b}}$ & $5.0^{\mathrm{c}}$ & 0.019 & 0.036 \\
Leafy vegetables $^{\mathrm{b}}$ & $3.0 \mathrm{E}-03_{\text {soil }}^{\mathrm{b}}$ & $3.0^{\mathrm{d}}$ & 0.106 & 0.203 \\
Other vegetables/ & $8.0 \mathrm{E}-04 \times[\mathrm{Pb}]_{\text {soil }} \mathrm{b}$ & $3.3^{\mathrm{d}, \mathrm{e}}$ & 0.044 & 0.084 \\
\hline
\end{tabular}

${ }^{\mathrm{a}}$ Dudka et al. (1996); ${ }^{\mathrm{b}}$ Attanayake et al. (2014); 'UK_GOV (2018);

${ }^{\mathrm{d}}$ STATIS (2011); ${ }^{\mathrm{e}}$ Zucchini as an example
Together with the wash-out (Eq. 5), Eq. 6 becomes

$\frac{d[P b]_{\text {soil }}}{d t}=I N-6 \times 10^{-3} a^{-1} \times[P b]_{\text {soil }}$.

Note: the input (IN) has to be expressed as $\mathrm{mg} /$ $(\mathrm{kg} \times \mathrm{a})$.For $[\mathrm{Pb}]_{t=0} \neq 0$, the exact solution of Eq. (7) is

$$
\begin{aligned}
{[P b]_{\text {soil }, t}=} & \frac{I N}{0.006} \times\{1-\exp (-0.006 \times t)\} \\
& +\left\{[\mathrm{Pb}]_{\text {soil }, t=0} \times \exp (-0.006 \times t)\right\},
\end{aligned}
$$

with $[\mathrm{Pb}]_{\mathrm{t}=0}$ being the $\mathrm{Pb}$ concentration in soil at the beginning of the observation period. This initial $\mathrm{Pb}$ concentration was set to $0.1 \mathrm{mg} / \mathrm{kg}$ for scenarios A1, B1, C1 and D1 $(0.1 \mathrm{mg} / \mathrm{kg}$ as control level for crop-fields) and $70 \mathrm{mg} / \mathrm{kg}$ for scenarios A2, B2, C2 and C2 $(70 \mathrm{mg} / \mathrm{kg}$ as precautionary level in silt soil).

\section{Oral exposure via crops}

For the exposure via plant food, the EU food basket for vegetarians was taken as the basis for the calculation (EFSA 2010), which includes consumption of eggs and dairy products (Table 4). Data for modeling the exposure pathway soil-cow-milk or soil-hen-egg were not available; therefore, only the human exposure trend via direct consumption of crops was modeled.

For children of $20 \mathrm{~kg}$ body weight (b.w.), the recommended daily food basket was taken as the basis for the calculations (Kersting et al. 2017). Although this includes meat, it was assumed that only direct crop intake adds to $\mathrm{Pb}$ exposure for children (Table 4). The daily uptake of $\mathrm{Pb}$ is estimated by multiplying these daily crop intakes with the relevant plant load of $\mathrm{Pb}$; these plant loads are dependent on the $\mathrm{Pb}$ content on soil and the uptake factors (UF, Table 3) and are calculated with Eqs. (1)-(4). The daily oral exposure via plant products was calculated as

Table 4 Plant food intake of adult vegetarians and children for different plant species

\begin{tabular}{lll}
\hline Plant species & $\begin{array}{l}\text { Daily intake adult vegetar- } \\
\text { ian }[\mathrm{kg} /(\text { person } \times \mathrm{d})]^{\mathrm{a}}\end{array}$ & $\begin{array}{l}\text { Daily intake child } \\
{[\mathrm{kg} /(\text { person } \times \mathrm{d})]^{\mathrm{b}}}\end{array}$ \\
\hline Cereals & 0.283 & 0.11 \\
Potatoes & 0.094 & 0.10 \\
Leafy vegetables & 0.318 & 0.19 \\
Other vegetables & 0.144 & 0.18 \\
\hline
\end{tabular}

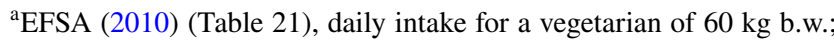
${ }^{b}$ recommended intake for a child of $20 \mathrm{~kg}$ b.w. (Kersting et al. 2017) 
Oral exposure by plant food $=[\mathrm{Pb}]_{\text {soil }} \times \sum_{i}\left\{(\text { daily intake })_{i} \times \mathrm{UF}_{i}\right\}$,

and the soil concentration of $\mathrm{Pb}$ was calculated according to Eq. (8).

\section{Risk evaluation}

For risk evaluation, the daily uptake was compared to the reference values for different toxicological endpoints. The margin of safety (MOS) was defined for toxicological endpoints having a threshold, whereas the margin of exposure (MOE) was allocated to carcinogenic effects driven by genotoxicity:

MOS or MOE $=\frac{\text { BMDL for toxicological endpoint }\left[\frac{\mathrm{mg}}{\mathrm{kg} b \cdot \mathrm{w} \cdot \times \mathrm{d}}\right]}{\text { daily exposure }\left[\frac{\mathrm{mg}}{\mathrm{kgb} \cdot \mathrm{w} \cdot \mathrm{xd}}\right]}$

The toxicity of $\mathrm{Pb}$ was summarized by reports of the US ATSDR (ATSDR 2007, 2019) and the EFSA (EFSA 2010). In terms of the respective BMDL, the most critical endpoints are neurodevelopmental toxicity in children and renal toxicity for adults. Kidney cancer may be identified as another critical endpoint, if $\mathrm{Pb}$ is to be regarded as a non-threshold carcinogen (see below).

For developmental neurotoxicity (dev.neu.), the dose-response analysis of the available epidemiological data resulted in a combined linear dose-response for oral exposure:

$\mathrm{BMDL}_{01 \text {,dev.neu. }}=12 \mu \mathrm{g} \mathrm{Pb} / \mathrm{L}$ blood $=0.5 \mu \mathrm{g} \mathrm{Pb} /(\mathrm{kg}$ b.w. $\times \mathrm{d})$

. (EFSA 2010; Budtz-Jorgensen et al. 2013).

Based on epidemiological data, the benchmark dose for chronic nephrotoxicity (neph.tox.) is,

$\mathrm{BMDL}_{01, \text { neph.tox. }}=15 \mu \mathrm{g} \mathrm{Pb} / \mathrm{L}$ blood $=0.63 \mu \mathrm{g} \mathrm{Pb} /(\mathrm{kg} \mathrm{b} . \mathrm{w} . \times \mathrm{d})$

, (EFSA 2010).

$\mathrm{As} \mathrm{Pb}$ can increase kidney tumor incidences in perinatal exposed mice without overt chronic nephropathy (Waalkes et al. 1995), the lower $95 \%$ confidence interval for $10 \%$ excess risk for kidney tumors is,

$\mathrm{BMDL}_{10 \text { (mouse, kidney cancer) }}=30.5 \mathrm{mg} \mathrm{Pb} / \mathrm{kg} \mathrm{b.w./ \textrm {d }}$

; with an oral scaling factor of 7, for human beings of $60 \mathrm{~kg}$ b.w., the result is,

$\mathrm{BMDL}_{10, \text { human beings }}=519 \mathrm{mg} /($ person $\times \mathrm{d})$

(see Supplemental Information).
For developmental neurotoxicity, as well as for nephrotoxicity, an MOS of 1 is deemed tolerable, as both endpoints are based on a broad epidemiological database. For kidney cancer, a minimum MOE of 10,000 is required. On this basis, a reverse-calculation may be run to estimate after how many years the $\mathrm{Pb}$ load in soil is so high that the tolerable daily intake (TDI) is met.

The corresponding $\mathrm{Pb}$ content in soil and the time interval to arrive that level are called $[\mathrm{Pb}]_{\text {soil, crit }}$ and $\mathrm{t}_{\text {crit }}$.

$$
\begin{aligned}
\operatorname{TDI}[\mu \mathrm{g} /(\text { person } \times \mathrm{d})]= & \sum_{i}\left(m_{i} \times \mathrm{UF}_{i}\right) \\
& \times[\mathrm{Pb}]_{\text {soil, crit. }} \leftrightarrow[\mathrm{Pb}]_{\text {soil, crit. }} \\
= & \mathrm{TDI} /\left\{\sum_{i}\left(m_{i} \times \mathrm{UF}_{i}\right)\right\}
\end{aligned}
$$

with $[\mathrm{Pb}]_{\text {soil, crit. }}$ being the critical $\mathrm{Pb}$ concentration in soil, $\mathrm{m}$ the mass of plant ingested per day and UF its uptake factor, summed up for each plant food species $i$. These calculations assume a constant, non-changing $\mathrm{Pb}$ input on soil over prolonged periods of time, and that plant food is the sole source of $\mathrm{Pb}$ exposure.

If in Eq. 8, $\mathrm{t}$ is very high, equilibrium will be established, and

$[\mathrm{Pb}]_{\text {soil }, t \rightarrow \infty}=\mathrm{IN} / \mathrm{k}=\mathrm{IN} / 0.006$.

If $[\mathrm{Pb}]_{\text {soil }, t \rightarrow \infty}>[\mathrm{Pb}]_{\text {soil,crit }}$, the scenario calls for reduction of $\mathrm{Pb}$ input into soil. Rearrangement of Eq. 8 allows to calculate the time period after which the critical soil concentration would be arrived at

$t_{\text {crit }}=-\frac{1}{k} \times\left\{\mathrm{LN}\left([\mathrm{Pb}]_{\text {soil,crit }}-\frac{\mathrm{IN}}{k}\right)-\mathrm{LN}\left([\mathrm{Pb}]_{\text {soil }, t=0}-\frac{\mathrm{IN}}{k}\right)\right\}$.

\section{Results}

\section{$\mathrm{Pb}$ input into soil}

The annual $\mathrm{Pb}$ input into agricultural soil was calculated using the medians and best estimates for deposition by (1) gunshot $(80 \mathrm{~g} /($ ha $\times \mathrm{a}),(2)$ background air deposition $(11 \mathrm{~g} /($ ha $\times \mathrm{a})$ and (3) fertilizer input. The contribution of fertilizer was based on a previous study that estimated $\mathrm{Pb}$ input into soil for four typical scenarios of conventional farming (Knappe et al. 2008). These four conditions, further named scenarios A-D, were calculated to cause a $\mathrm{Pb}$ input by fertilizer of 7.5, 313.0, 69.5 or $6.3 \mathrm{~g} /($ ha $\times \mathrm{a})$, and for all three sources a total $\mathrm{Pb}$ input of 98.5, 405.6, 171.7 and $98.8 \mathrm{~g} /($ ha $\times \mathrm{a})$, respectively (Fig. 2). The highest $\mathrm{Pb}$ input on soil was obtained for scenario $\mathrm{B}$, the lowest (and very similar) inputs for scenarios A and D, while scenario $\mathrm{C}$ was intermediate. 


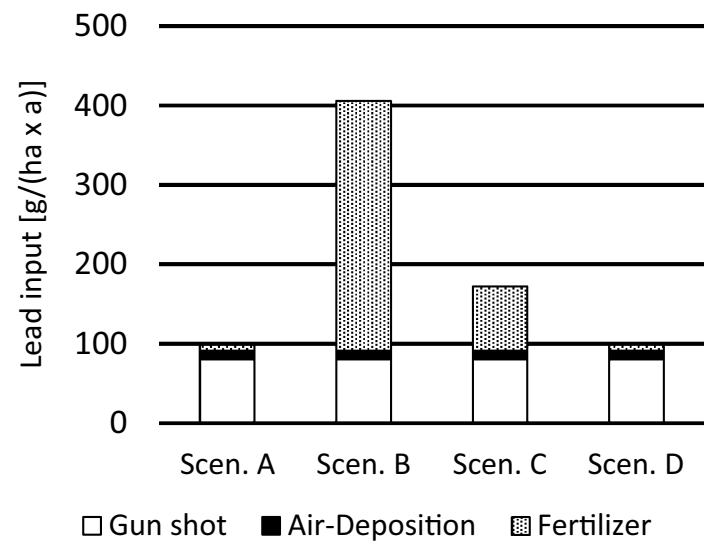

Fig. 2 Annual $\mathrm{Pb}$ input on fields by gun shot, air deposition and fertilizer, $g /($ ha $\times a)$ for four different farming scenarios (Knappe et al. 2008): Scenario A use of cattle manure and mineral fertilizer; Scenario $\mathbf{B}$ use of compost and mineral fertilizer; Scenario $\mathbf{C}$ use of sewage sludge and mineral fertilizer; Scenario $\mathbf{D}$ exclusive use of mineral fertilizer

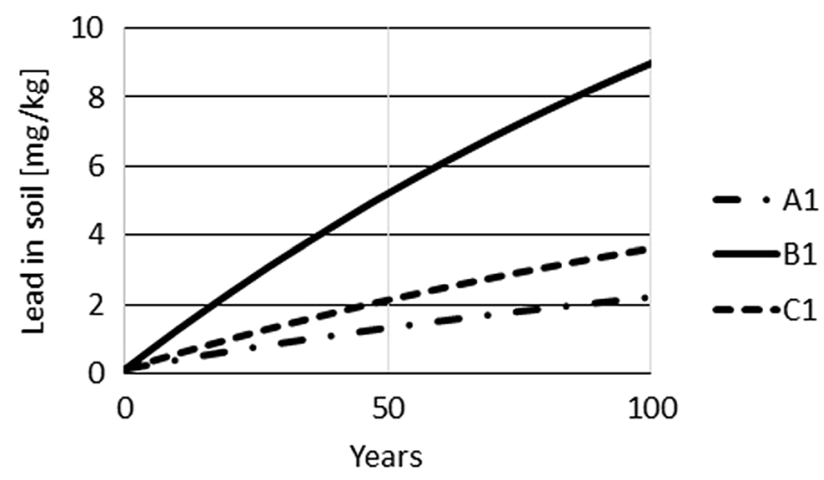

Fig. 3 Simulation of $\mathrm{Pb}$ concentrations in soil for 100 years for $\mathrm{Pb}$ input scenarios $\mathrm{A} 1, \mathrm{~B} 1$ and $\mathrm{C} 1$

\section{Time-dependent simulation of $\mathrm{Pb}$ concentrations in farmland}

The time-dependent $\mathrm{Pb}$ concentrations in farmland were simulated using Eq. (8). For these simulations, a constant input of $\mathrm{Pb}$ on soil was assumed for very long periods. As the $\mathrm{Pb}$ input for farming scenarios A and D is very similar, the following calculations were only performed for farming scenarios A-C. The initial soil concentration of $\mathrm{Pb}$ was set to (1) $0.1 \mathrm{mg} / \mathrm{kg}$, the control level for crop fields; and (2) $70 \mathrm{mg} / \mathrm{kg}$, the precautionary level for silt-soil. Therefore, a total of 6 scenarios were simulated, A1-C1 with initial soil concentrations of $0.1 \mathrm{mg} / \mathrm{kg}$ and A2-C2 with initial soil concentrations of $70 \mathrm{mg} / \mathrm{kg}$. Simulations of time-dependence show that approximately 100 years are required until $\mathrm{Pb}$ concentrations increase from an initial concentration of $0.1 \mathrm{mg} / \mathrm{kg}(\mathrm{mg} / \mathrm{kg}$ ) to 2 (A1), 4 (C1) or 9 (B1) $\mathrm{mg} / \mathrm{kg}$ (Fig. 3). The simulation also demonstrates that changes within the first 10 years are relatively small, not exceeding an

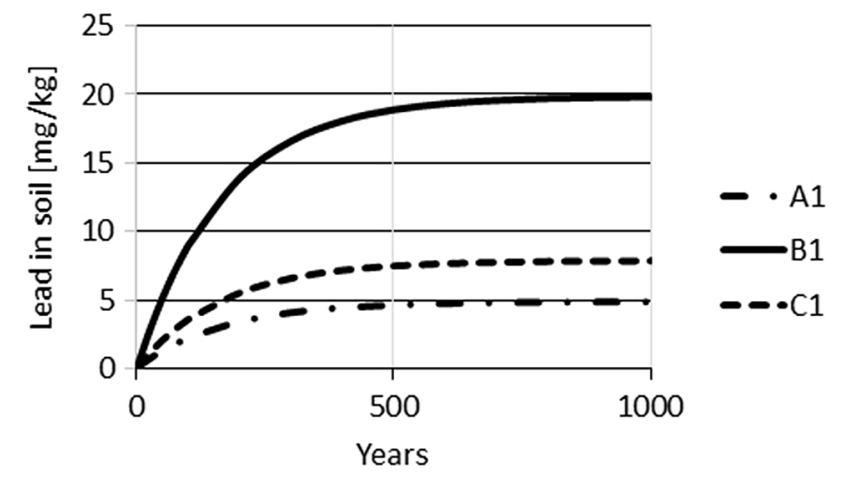

Fig. 4 Long-term simulation of $\mathrm{Pb}$ concentrations under the same input scenarios shown in Fig. 3

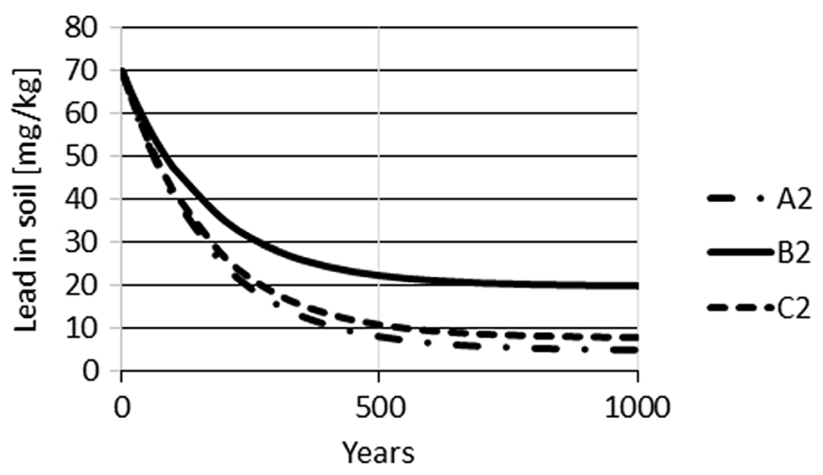

Fig. 5 Time-dependent $\mathrm{Pb}$ concentration in soil for scenarios A2, B2 and $\mathrm{C} 2$ for constant $\mathrm{Pb}$ input

increase of $2 \mathrm{mg} / \mathrm{kg}$ for all three scenarios. Equilibrium levels for $\mathrm{Pb}$ of approximately 5, 20 and $8.5 \mathrm{mg} / \mathrm{kg}$ in soil were predicted to be reached for scenarios A1, B1 and C1, respectively, only after about 600 years (Fig. 4). If the initial concentration is set to $70 \mathrm{mg} / \mathrm{kg}$, planting and harvest result in a reduction of $\mathrm{Pb}$ in soil over time until the same equilibrium concentrations would be reached as for the staring situation with $0.1 \mathrm{mg} / \mathrm{kg}$. However, approximately 600 years would be required until these equilibrium levels are achieved (Fig. 5).

\section{Critical soil levels}

The oral exposure of humans due to consumption of crops was simulated for the different scenarios. As $70 \mathrm{mg} / \mathrm{kg} \mathrm{Pb}$ content in soil is above the control level of the German Soil Protection Ordinance, we focused on scenarios A1, B1, C1 and D1, in which the initial soil concentration is $0.1 \mathrm{mg} / \mathrm{kg}$.

Using Eq. 10 and data from Tables 3 (UF), 4 (m) and 5 , the critical soil concentration, $[\mathrm{Pb}]_{\text {soil }, \text { crit, }}$, was calculated (Table 6).

Equilibrium concentrations of $\mathrm{Pb}$ according to the farming scenario were calculated using Eq. 11 (Fig. 6). For scenario B1, the equilibrium concentration exceeds the critical soil 
Table 5 TDI values $[\mu \mathrm{g} /($ person $\times \mathrm{d})]$ as defined in the text

\begin{tabular}{lll}
\hline Toxicological Endpoint & $\begin{array}{l}\text { TDI Child }^{\mathrm{a}} \\
{[\mu \mathrm{g} /(\text { person } \times \mathrm{d})]}\end{array}$ & $\begin{array}{l}\text { TDI } \\
\text { Adult }^{\mathrm{b}} \\
{[\mu \mathrm{g} /} \\
(\mathrm{per}- \\
\text { son } \times \mathrm{d})]\end{array}$ \\
\hline $\begin{array}{l}\text { Developmental Neurotoxicity } \\
\text { Renal failure }\end{array}$ & 10 & - \\
Kidney cancer & - & 38 \\
\hline
\end{tabular}

${ }^{\mathrm{a}} 20 \mathrm{~kg}$ b.w.; ${ }^{\mathrm{b}} 60 \mathrm{~kg}$ b.w

Table 6 Critical soil concentrations according to Eq. 10

\begin{tabular}{lll}
\hline Toxicological Endpoint & $\begin{array}{l}\text { TDI }[\mu \mathrm{g} /(\text { person } \\
\times \mathrm{d})]\end{array}$ & $\begin{array}{l}{[\mathrm{Pb}]_{\text {soil, crit. }}[\mathrm{mg} /} \\
\mathrm{kg}]\end{array}$ \\
\hline Developmental Neurotoxicity & $10^{\mathrm{a}}$ & 5 \\
Renal failure & $38^{\mathrm{b}}$ & 18 \\
Kidney cancer & $52^{\mathrm{b}}$ & 25 \\
\hline
\end{tabular}

The $\mathrm{Pb}$ concentrations in soil are given $\left(\mathrm{Pb}_{\text {soil }}, \mathrm{mg} / \mathrm{kg}\right)$ that were simulated to correspond to the specific tolerable daily intake (TDI) for three toxicological endpoints ${ }^{\mathrm{a}} 20 \mathrm{~kg}$ b.w.; ${ }^{\mathrm{b}} 60 \mathrm{~kg}$ b.w

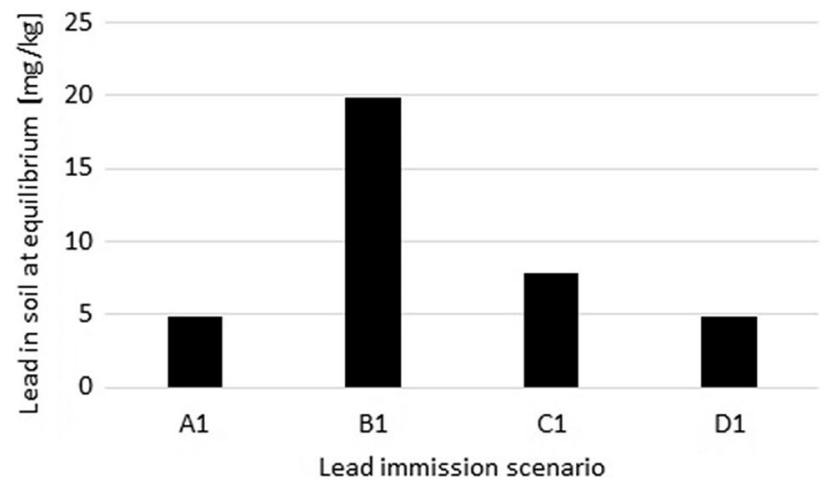

Fig. 6 Equilibrium soil concentration of $\mathrm{Pb}$ according to four farming scenarios

concentration of $\mathrm{Pb}$ for both renal failure and developmental neurotoxicity, whereas scenario $\mathrm{C} 1$ exceeds the critical soil concentrations of $\mathrm{Pb}$ for developmental neurotoxicity only.

It is important to predict the number years of a specific $\mathrm{Pb}$ input required for critical soil concentrations for developmental neurotoxicity to be exceeded. Therefore, simulations for scenario $\mathrm{B} 1$ and $\mathrm{C} 1$ were performed with different initial $\mathrm{Pb}$ concentrations in soil as a starting situation (Fig. 7). Assuming a concentration of $0.1 \mathrm{mg} / \mathrm{kg} \mathrm{Pb}$ in soil, approximately 50 years of $\mathrm{Pb}$ input according to scenario B1 would be required to exceed the critical soil concentration; for scenario $\mathrm{C} 1$, this period increases to approximately 175 years. With increasing initial $\mathrm{Pb}$ concentrations, the periods gradually decrease (Fig. 7). For an initial $\mathrm{Pb}$

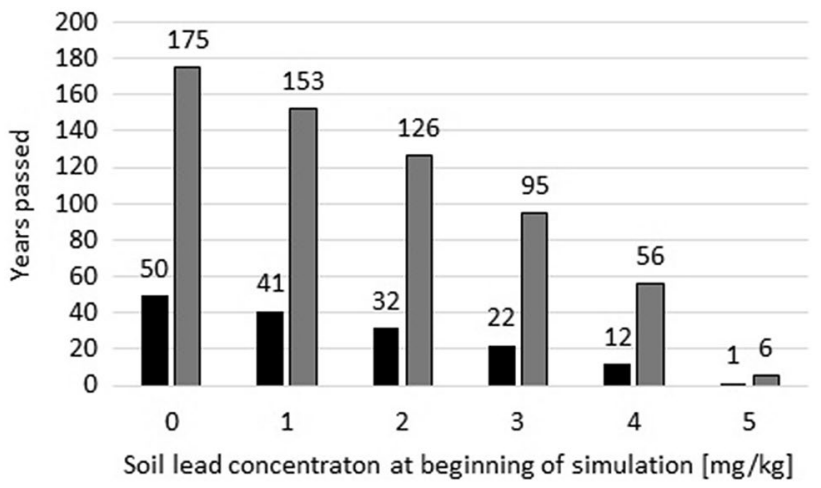

Fig. 7 Time periods in years until critical soil concentration of $\mathrm{Pb}$ would be exceeded with respect to developmental neurotoxicity. The simulations are based on farming scenario B1 (black bars) and C1 (grey bars). The initial $\mathrm{Pb}$ concentration in soil are given on the $\mathrm{x}$-axis

concentration of $5 \mathrm{mg} / \mathrm{kg}$, the respective periods are only 1 and 6 years for scenarios B1 and C1, respectively. With the lowest critical level of $\mathrm{Pb}$ in soil of $5 \mathrm{mg} / \mathrm{kg}$, the annual input should not exceed about $10 \mathrm{mg} /\left(\mathrm{m}^{2} \times \mathrm{a}\right)=100 \mathrm{~g} /(\mathrm{ha} \times \mathrm{a})$ in order not to exceed critical soil concentrations.

\section{Discussion}

In recent years, human exposure to $\mathrm{Pb}$ has been decreased by several measures (Wietlisbach et al. 1995; Pirkle et al. 1994). Nevertheless, there is still persistent immission of $\mathrm{Pb}$ onto agricultural soils; the major sources are from the use of fertilizer, $\mathrm{Pb}$ ammunition from hunting activities, and $\mathrm{Pb}$ from air deposition. Little is known whether current immission is high enough to cause an increase of $\mathrm{Pb}$ concentrations in agricultural soil over prolonged periods. If so, the questions raised are regarding the level of the resulting equilibrium concentration, the time span until equilibrium would be established, and whether critical concentrations would be reached for consumers of agricultural products. To answer these questions, we performed simulations of $\mathrm{Pb}$ concentrations in soil, using different previously reported input scenarios. A main result of these simulations is that current input scenarios would require very long periods of approximately 600 years until new equilibrium concentrations would be established, where the $\mathrm{Pb}$ input equals $\mathrm{Pb}$ removal by the harvest of plants and by washout. We calculated that a concentration of $\sim 5 \mathrm{mg} / \mathrm{kg} \mathrm{Pb}$ in agricultural soil leads to an intake of approximately $10 \mu \mathrm{g} \mathrm{Pb}$ per person per day by consumption of representative amounts of agricultural products obtained from this soil; $10 \mu \mathrm{g}$ per person per day is considered as the tolerable daily intake (TDI) based on data on developmental neurotoxicity. Therefore, the concentration of $5 \mathrm{mg} / \mathrm{kg} \mathrm{Pb}$ was considered a critical concentration in soil that should not be exceeded. Starting 
with a soil concentration of $0.1 \mathrm{mg} / \mathrm{kg}$, the control level for crop fields, our simulation predicts periods between 50 and 175 years until the critical concentration of $5 \mathrm{mg} / \mathrm{kg} \mathrm{Pb}$ in soil would be reached, depending on the immission scenario.

In our model, air deposition, application of fertilizer and hunting with gunshot were included as sources for $\mathrm{Pb}$ input in agricultural soil. For fertilizers, compost is the major contributor of $\mathrm{Pb}$ (Knappe et al. 2008), and for scenario B, the relevance of $\mathrm{Pb}$ sources is fertilizer $>$ hunting $>$ air deposition. For scenarios $\mathrm{A}, \mathrm{C}$ and $\mathrm{D}$, hunting with gunshot is the major contributor for $\mathrm{Pb}$ input in soil, while fertilizer contributes most in scenario B. As our calculations demonstrate, it may take several hundreds of years before $\mathrm{Pb}$ in soil has achieved an equilibrium starting from boundary values of 0 or $70 \mathrm{mg} / \mathrm{kg}$. Although several measures were taken to reduce the $\mathrm{Pb}$ input into soil over the last decades, it is likely that equilibria have not yet been reached. It is unlikely that $\mathrm{Pb}$ concentrations in agricultural soil will decrease over the next decades; contrary to this, soils with currently low $\mathrm{Pb}$ concentrations may exceed critical levels in the future. It should be considered that all predictions of the present study were made under the assumption that the $\mathrm{Pb}$ input on soil will not change in the future. In Europe, $\mathrm{Pb}$ in soil ranges from $<10$ to $>70 \mathrm{mg} / \mathrm{kg}$, with a median of $23 \mathrm{mg} / \mathrm{kg}$ (EFSA 2010). According to our model, the lowest critical soil level is $5 \mathrm{mg} / \mathrm{kg}$; the maximum permissible input on soil should, therefore, not exceed $10 \mathrm{mg} /\left(\mathrm{m}^{2} \times \mathrm{a}\right)$, corresponding to $100 \mathrm{~g} /($ ha $\times$ a) ; these conditions are fulfilled in scenarios $\mathrm{A} 1$ and D1. A maximum input of $100 \mathrm{~g} /($ ha $\times a)$ should also be protective with respect to renal failure and kidney cancer, endpoints, for which data show the effects only with higher doses than for development neurotoxicity. However, the conclusion is based on the assumption that plant food is the sole source for $\mathrm{Pb}$ exposure. The German Federal Soil Protection and Contaminated Sites Ordinance (BMJV 2017) currently names a maximum permissible input of $400 \mathrm{~g} \mathrm{~Pb}$ per ha and year, which is only slightly exceeded by scenario B1.

A further question addressed by the simulations is the time period required until the $\mathrm{Pb}$ concentration in contaminated soil is reduced to lower equilibrium levels. For this purpose, scenarios A2, B2 and C2 were applied, starting at relatively high levels of $\mathrm{Pb}$ in soil. Uptake of $\mathrm{Pb}$ by plants may reduce its concentrations in soil, a mechanism known as phytoremediation (Kushwaha et al. 2018). The simulations demonstrated that several centuries would be required until lower equilibrium concentrations of $\mathrm{Pb}$ in soil would be established.

Whether or not $\mathrm{Pb}$ is a non-threshold genotoxic carcinogen is debatable. The German MAK Commission classified inorganic $\mathrm{Pb}$ compounds as carcinogen MAK-category 2 (equivalent to GHS category 1B); (DFG 2009). In their evaluation, EFSA considered $\mathrm{Pb}$ as a weak, probably indirect mutagen, increasing kidney tumor incidents in rodents at comparatively high dosages (EFSA 2010). The International Agency for
Research on Cancer concluded that there is only limited evidence for direct DNA interaction, whereas inhibition of DNA repair and oxidative stress are involved in $\mathrm{Pb}$ genotoxicity (IARC 2006). In any case, we estimated the $\mathrm{BMDL}_{10}$ for kidney cancer based on the data of Waalkes et al. (1995) and used this as a point of departure for the MOE calculation.

The models used for our simulations have several limitations and contain assumption and simplifications. First, we assumed a linear relationship between $\mathrm{Pb}$ uptake by plants and the $\mathrm{Pb}$ content in soil. This assumption is debatable. According to Knappe et al. (2008), Pb content in soil results in $\mathrm{Pb}$ in plants but the quantitative relationship may not necessarily be linear. For example, in curly kale, $20 \mathrm{mg} / \mathrm{kg} \mathrm{Pb}$ in the soil resulted in plant contents between 1 and $10 \mathrm{mg} / \mathrm{kg}$, and $\sim 60 \mathrm{mg} / \mathrm{kg} \mathrm{Pb}$ in soil resulted in measured plant contents of $1-35 \mathrm{mg} / \mathrm{kg}$. Using our model, the calculated content for leafy vegetables was 0.03 and $0.18 \mathrm{mg} / \mathrm{kg}$ for soil contents of 10 and $60 \mathrm{mg} / \mathrm{kg}$, respectively, which is lower compared to Knappe et al. (2008). Wang et al. (2006) investigated $\mathrm{Pb}$ uptake in vegetables and derived a sublinear relationship, for example for leafy vegetables, $[\mathrm{Pb}]_{\text {plant }}=0.03 \times[\mathrm{Pb}]_{\text {soil }}^{0.33}$. This relation will result in a saturated plant-uptake for increasing $\mathrm{Pb}$ concentrations in soil. Using this formula for leafy vegetables would result in a 14-fold higher $\mathrm{Pb}$ content in the plant for $0.1 \mathrm{mg} / \mathrm{kg} \mathrm{Pb}$ in soil, and 2.5-fold lower $\mathrm{Pb}$ content in the plant for $20 \mathrm{mg} / \mathrm{kg} \mathrm{Pb}$ in soil, compared to our model. Since Wang et al. (2006) have not published data for cereals and root crops, and because Attanayake et al. (2014) and Dudka et al. (1996) worked with partly highly contaminated soils, we decided to apply a linear uptake model in the present study. Taken together, our model tends to underestimate oral exposure to $\mathrm{Pb}$ via plant food than to overestimate it. Second, the input of $\mathrm{Pb}$ by gunshot was assumed to be homogenous in the present model, which in reality is not the case. The bullets present dispersed $\mathrm{Pb}$ centers in the soil, where they disintegrate (Rooney et al. 2007); the $\mathrm{Pb}$ input on soil by gunshot is a rough estimate, based on market volumes and the potential hunting area in the EU. More robust immission data are desirable for a more robust estimate of the contribution of gunshot to soil $\mathrm{Pb}$ burden. Third, we assumed that the top $20 \mathrm{~cm}$ soil layer is relevant for mixing and exchange of $\mathrm{Pb}$. Nevertheless, although we have introduced these simplifications, $\mathrm{Pb}$ content in crops and $\mathrm{Pb}$ in soil modeled with scenarios $\mathrm{A}, \mathrm{B}$, $\mathrm{C}$ and $\mathrm{D}$ do match measured values reported in other publications (EFSA 2010, 2012; Toth et al. 2016). Concerning oral exposure to $\mathrm{Pb}$, plant products cover up to $40 \%$ and beverages up to $23 \%$ of the burden for adults; the median oral exposure in the EU is estimated to be approximately $0.9,1.3,1.0$ and $0.5 \mu \mathrm{g} / \mathrm{kg}$ b.w./day for infants, toddlers, other children and adults, respectively; the 95-percentile was estimated to be approximately $1.8,2.2,1.7$ and $0.8 \mu \mathrm{g} / \mathrm{kg}$ b.w./day for infants, toddlers, other children and adults, respectively (EFSA 2012). Forth, we assumed that cooking does not reduce the $\mathrm{Pb}$ load 
in plant food, which is a reasonable assumption considering that food preparation does not significantly reduce the $\mathrm{Pb}$ content in fish (Diaconescu et al. 2013). Only in the case of the preparation of acidified food it is possible that some $\mathrm{Pb}$ is extracted from the plant material. Finally, it should be considered that besides the simulated sources (air deposition, fertilizer and gunshot), humans may also be exposed to $\mathrm{Pb}$ via drinking water. The limit value for $\mathrm{Pb}$ in drinking water is $10 \mu \mathrm{g} / \mathrm{L}$ (WHO 2017; TrinkwasserVO 2018). With a daily consumption of $1-2 \mathrm{~L}$ per person and day, this potential additional source of $\mathrm{Pb}$ exposure can reduce the margin of safety calculated here. Further, $\mathrm{Pb}$ in soil may contribute to the $\mathrm{Pb}$ burden in ground water. However, the drift velocity of $\mathrm{Pb}$ anions in soil is slow; therefore, $\mathrm{Pb}$ dispersed onto soil may cause problems not earlier than after several decades (see Supplemental Information).

Measures to reduce future oral $\mathrm{Pb}$ exposure via plant food should address the $\mathrm{Pb}$ content in compost. This problem was also investigated by other authors, including Dai et al. (2006), Singh et al. (2010), Lopes et al. (2011) and Eid et al. (2017). Methods for heavy metal reduction in organic material and sludge have been published (e.g., Vogel et al. 2013). Such processes are sophisticated and require technical and financial efforts. Over the last two decades, the median level of $\mathrm{Pb}$ in compost decreased from $52 \mathrm{mg} / \mathrm{kg}$ (d.w.) in 1999 , to $31,28.3$ and $27.0 \mathrm{mg} / \mathrm{kg}$ (d.w.) in 2012, 2015 and 2018, respectively (Hermann et al. 2017; Bundesgütegemeinschaft-Kompost 2019).

Next to compost, hunting with gunshot is the most important contribution of $\mathrm{Pb}$ input into agricultural soil. Substitution of $\mathrm{Pb}$ in hunting ammunition by less problematic materials would not only reduce oral $\mathrm{Pb}$ exposure via plant food, but also reduce exposure caused by the consumption of game meat (Pain et al. 2010; Mueller-Graf et al. 2017).

Due to the severe toxic effects caused by $\mathrm{Pb}$, it is recommended to closely supervise future developments in $\mathrm{Pb}$ levels in the environment and the dietary $\mathrm{Pb}$ exposure of consumers. Comparatively simple measures to reduce the long-term exposure to $\mathrm{Pb}$ are possible and should not be postponed.

Acknowlegements Open Access funding provided by Projekt DEAL.

\section{Compliance with ethical standards}

Conflict of interest This study has been conducted by the Advisory Committee of the German Society of Toxicology (AC). The AC is elected by the members of the German Society of Toxicology and consists of representatives from academia, industry and administration to guarantee a broad range of toxicological competence. The AC presents and justifies its activities to the members of the German Society of Toxicology, for example, at the yearly plenary meeting. The German Society of Toxicology is the largest scientific toxicological organization in Europe, with more than 1300 members. In the past 10 years, the Advisory Committee has already published review articles about inorganic arsenic in food (Gundert-Remy et al. 2015), nanotoxicology
(Gebel et al. 2014), bisphenol A (Hengstler et al. 2011), alternative methods to animal experiments (Lilienblum et al. 2008) and REACH (Hengstler et al. 2006). Commentaries to hydraulic fracturing have not yet been published by the AC.

Open Access This article is licensed under a Creative Commons Attribution 4.0 International License, which permits use, sharing, adaptation, distribution and reproduction in any medium or format, as long as you give appropriate credit to the original author(s) and the source, provide a link to the Creative Commons licence, and indicate if changes were made. The images or other third party material in this article are included in the article's Creative Commons licence, unless indicated otherwise in a credit line to the material. If material is not included in the article's Creative Commons licence and your intended use is not permitted by statutory regulation or exceeds the permitted use, you will need to obtain permission directly from the copyright holder. To view a copy of this licence, visit http://creativecommons.org/licenses/by/4.0/.

\section{References}

ATSDR (2007) Toxicological Profile for Lead. Atlanta, Georgia 30333: Agency for toxic substances and disease registry. Division of Toxicology and Environmental Medicine/Applied Toxicology Branch. 2007. https://www.atsdr.cdc.gov/ToxProfiles/tp13.pdf.Accessed 5 May 2018. Accessed 12 Dec 2019.

ATSDR (2019) Toxicological profile for lead. Atlanta, Georgia 30333: agency for toxic substances and disease registry. Division of toxicology and environmental medicine/applied toxicology branch. Public draft for comment. https://www.atsdr.cdc.gov/toxprofiles/ tp13.pdf. Accessed 3 Feb 2020

Attanayake CP, Ganga M, Harms A, Presley D, Martin S, Pierzynsi GM (2014) Field evaluations on soil plant transfer of lead from an urban garden soil. J Environ Qual 43(2):475-487. https://doi. org/10.2134/jeq2013.07.0273

BMJV (2017) Bundesministrerium der Justiz und für Verbraucherschutz. Bundes-Bodenschutz- und Altlastenverordnung vom 12. Juli 1999 (BGBl. I S. 1554), die zuletzt durch Artikel 3Absatz 4 der Verordnung vom 27. September 2017 (BGB1. I S. 3465) geändert worden ist. https://www.gesetze-im-internet.de/bbods chv/BBodSchV.pdf. Accessed 12 Dec 2019

Budtz-Jorgensen E, Bellinger D, Lanphear B, Grandjean P (2013) An international pooled analysis for obtaining a benchmark dose for environmental lead exposure in children. Risk Anal 33(3):450 461. https://doi.org/10.1111/j.1539-6924.2012.01882.x

Bundesgütegemeinschaft-Kompost (2019) Auswertung der Gütegesicherten Kompostanalysen 2018. https://www.kompost.de/filea dmin/user_upload/Dateien/Zahlen/Kolmpost_D_2018.pdf. Accessed 12 Dec 2019

Dai J-Y, Chen L, Zhao J-F, Ma N (2006) Characteristics of sewage sludge and distributions of heavy metals in plants with amendment of sewage sludge. J Environ Sci 18(6):1094-1100. https:// doi.org/10.1016/S1001-0742(06)60045-4

DFG (2009) Deutsche Forschungsgemeinschaft: Lead and its inorganic compounds (inhalable fraction). [MAK Value Documentation, 2009]. https://onlinelibrary.wiley.com/doi/10.1002/3527600418 .mb743992e0025/full. Accessed 18 Aug 2017

Diaconescu C, Fantaneru G, Urdes L, Vidu L, Vasile B, Diaconescu S (2013) Influence of cooking methods over the heavy metal and lipid content of fish meat. Rom Biotech Lett 18(3):8279-8283

Dudka S, Piotrowska M, Terelak H (1996) Transfer of cadmium, lead and zinc from industrially contaminated soil to crop plants: a field study. Environ Poll 94(2):181-188. https://doi.org/10.1016/s0269 -7491(96)00069-3 
EC (2017) European Commission: Agricultural and Rural Development. CAP Context Indicators 2014-2020. 18: Agricultural Area. [Online]. https://ec.europa.eu/agriculture/cap-indicators/conte xt/2017/c18_en.pdf. Accessed 12 Dec 2018

ECHA (2018a). European Chemicals Agency. https://www.echa.europ a.eu/de/web/guest/candidate-list-table/-/dislist/details/0b023 6e182607ea6. Accessed 20 Aug 2019

ECHA (2018b). A review of the available information on lead in shot used in terrestrial environments, in ammunition and in fishing tackle. European Chemicals Agency. 2018b. https://echa.europ a.eu/documents/10162/13641/lead_ammunition_investigation_ report_en.pdf/efdc0ae4-c7be-ee71-48a3-bb8abe20374a. Accessed 21 Sep 2018

EFSA (2010) Scientific opinion on lead in food. EFSA J 8(4):1570. https://www.efsa.europa.eu. Accessed 16 Aug 2017

EFSA (2012). Lead dietary exposure in the European population. EFSA J 10(7):2831. https://efsa.onlinelibrary.wiley.com/doi/ pdf/10.2903/j.efsa.2012.2831. Accessed on 09 Jul 2019

Eid EM, Alrumman SA, El-Bebany AF, Hesham AE-L, Taher MA, Fawy KF (2017) The effects of different sewage sludge amendment rates on the heavy metal bioaccumulation, growth and biomass of cucumbers (Cucumis sativus L.). Environ Sci Pollut Res 24:16371-16382. https://doi.org/10.1007/s11356-017-9289-6

EUSES (2004) European Union System for the Evaluation of Substances 2.0. Prepared for the European Chemicals Bureau by the National Institute of Public Health and the Environment (RIVM), Bilthoven, The Netherlands (RIVM Report no. 601900005). Available at European Chemicals Bureau. https://ecb.jrc.it. Accessed 7 Sept 2019

Gebel T, Foth H, Damm G, Freyberger A, Kramer PJ, Lilienblum W, Röhl C, Schupp T, Weiss C, Wollin KM, Hengstler JG (2014) Manufactured nanomaterials: categorization and approaches to hazard assessment. Arch Toxicol 88(12):2191-2211. https://doi. org/10.1007/s00204-014-1383-7

Gundert-Remy U, Damm G, Foth H, Freyberger A, Gebel T, Golka K, Röhl C, Schupp T, Wollin KM, Hengstler JG (2015) High exposure to inorganic arsenic by food: the need for risk reduction. Arch Toxicol 89(12):2219-2227. https://doi.org/10.1007/s0020 4-015-1627-1

Hawkins JL, Sheppard MI, Jorgensen SS (1995) Predicting soil lead migration: how can ancient church roofs help? Sci Total Environ 166:43-53. https://doi.org/10.1016/0048-9697(95),04516-4

Hengstler JG, Foth H, Kahl R, Kramer PJ, Lilienblum W, Schulz T, Schweinfurth H (2006) The REACH concept and its impact on toxicological sciences. Toxicology 220(2-3):232-239

Hengstler JG, Foth H, Gebel T, Kramer PJ, Lilienblum W, Schweinfurth H, Völkel W, Wollin KM, Gundert-Remy U (2011) Critical evaluation of key evidence on the human health hazards of exposure to bisphenol A. Crit Rev Toxicol 41(4):263-291. https://doi. org/10.3109/10408444.2011.558487

Hermann T, Weiss V, Bannick CG, Ehlers K, Claussen U (2017) Bioabfallkomposte und -gärreste in der Landwirtsdchaft. Umweltbundesamt, Fachgebiet III 2.4, Postfach 1406, 06813 Dessau-Roßlau, Germany. https://www.umweltbundesamt.de/publikationen/bioabfallk omposte-gaerreste-in-der-landwirtschaft. Accessed 14 Sept 2019

IARC (2006) International Agency for Research on Cancer. Monographs on the evaluation of carcinogenic risks to humans. VOLUME 87: Inorganic and Organic Lead Compounds. https://monog raphs.iarc.fr/wp-content/uploads/2018/06/mono87.pdf. Accessed 25 Jan 2019

Kersting M, Kahlhoff H, Luecke T (2017) From nutrients to food and meals: the conecept of the optimixed mixed diet for children and adolescents in Germany. Aktuelle Ernaehrungsmedizin 42:304315. https://doi.org/10.1055/s-0043-116499

Knappe F, Möhler S, Ostermayer A, Lazar S, Kaufmann C (2008) Vergleichende Auswertung von Stoffeinträgen in Böden über verschiedene Eintragspfade. 06813 Dessau-Roßlau: Umweltbundesamt, 2008. Forschungsbericht 203(74):275. https://www. umweltbundesamt.de/sites/default/files/medien/publikation/ long/3644.pdf. Accessed 28 Oct 2017

Kushwaha A, Hans N, Kumar S, Rani R (2018) A critical review on speciation, mobilization and toxicity of lead in soil-microbeplant system and bioremediation strategies. Ecotoxicol Environ Saf 147:1035-1045. https://doi.org/10.1016/j.ecoenv.2017.09.049

Lilienblum W, Dekant W, Foth H, Gebel T, Hengstler JG, Kahl R, Kramer PJ, Schweinfurth H, Wollin KM (2008) Alternative methods to safety studies in experimental animals: role in the risk assessment of chemicals under the new European Chemicals Legislation (REACH). Arch Toxicol 82(4):211-236. https://doi. org/10.1007/s00204-008-0279-9

Lopes C, Herva M, Franco-Uria A, Roca E (2011) Inventory of heavy metal content in organic waste applied as fertilizer in agriculture: evaluating the risk of transfer into the food chain. Environ Sci Pollut Res 18:918-939. https://doi.org/10.1007/s11356-011-0444-1

LUBW (2006) Schwermetalle in Regenwuermern Baden-Wuerttembergs. Landesanstalt fuer Umwelt, Messungen und Naturschutz, Baden-Wuerttemberg, Geermany. Dokumentation und Ergebnisbericht, Februar 2006. https://fachdokumente.lubw.baden-wuert temberg.de/servlet/is/20100/lubws10.pdf?command=downloadCo ntent\&filename $=$ lubws10.pdf\&FIS=199. Accessed 07 Jul 2019

Mueller-Graf C, Gerofke A, Martin A, Bandick N, Lahrssen-Wiederholt M, Schafft H-A, Selhorst T, Ulbig E, Hensel A (2017) Reduction of lead contents in game meat: results of the 'Food safety of game meat obtained through hunting' research project. In: Paulsen P, Bauer A, Smulders FJM (ed.) Game meat hygiene. Food safety and security. Wageningen Academic Publishers, Wageningen. 2017. Doi: 10.3920/978-90-8686-840-7. Accessed 18 Nov 2018

O'Connor D, Hou D, Ye J, Zhang Y, Ok YS, Song Y, Coulon F, Peng T, Tian L (2018) Lead-based paint remains a major public health concern: a critical review of global production, trade, use, exposure, health risk, and implications. Environ Int 121:85-101. https ://doi.org/10.1016/j.envint.2018.08.052

Pain DJ, Cromie RL, Newth J, Brown MJ, Crutcher E, Hardman P, Hurst L, Mateo R, Meharg AA, Moran AC, Raab A, Taggart MA, Green RE (2010) Potential hazard to human health from exposure to fragments of lead bullets and shot in the tissues of game animals. PLoS ONE 5(4):e10315. https://doi.org/10.1371/journ al.pone.0010315

Pirkle JL, Brody DJ, Gunter EW, Kramer RA, Paschal DC, Flegal KM, Matte TD (1994) The decline in blood lead levels in the United States. JAMA 272(4):284-291. https://doi.org/10.1001/ jama.1994.03520040046039

Rooney CP, McLaren RG, Condron LM (2007) Control of lead solubility in soil contaminated with lead shot: effect of soil $\mathrm{pH}$. Environ Pollut 149:149-157. https://doi.org/10.1016/j.envpol.2007.01.009

Schröder W, Nickel S (2019) Spatial structures of heavy metals and nitrogen accumulation in moss specimens sampled sampled between 1990 and 2015 throughout Germany. Environ Sci Eur 31:33. https://doi.org/10.1186/s12302-019-0216-y

Singh RP, Agrawal M (2010) Variations in heavy metal accumulation, growth and yield of rice plants grown at different sewage sludge amendment rates. Ecotoxicol Environ Saf 73:632-641. https://doi. org/10.1016/j.ecoenv.2010.01.020

STATIS. Statistisches Bundesamt: Land- und Forstwirtschaft, Fischerei (2011) https://www.destatis.de/DE/Publikationen/Thematisch /LandForstwirtschaft/ErnteGemuese/GemueseJahr203032111 7134.pdf?_blob=publicationFile. Accessed 07 Dec 2018

Schaap M, Hendriks C, Jonkers S, Builtjes P (2018) Impacts of heavy metal emission on air quality and ecosystems across Germany-Part 1. Texte 106/2018. Umweltbundesamt, Wörlitzer Platz 1, 06844 Dessau-Roßlau (Germany). https://www. umweltbundesamt.de/sites/default/files/medien/1410/publikatio 
nen/2018-12-13_texte_106-2018_schwermetallemissionen_ en.pdf. Accessed 28 Jan 2019

TrinkwasserVO (2018) Verordnung zur Neuordnung trinkwasserrechtlicher Vorschriften. Bundesgesetzblatt 2018 Teil I Nr. 2. Bonn, 8. Januar 2018. Germany

Toth G, Hermann T, Da Silva MR, Montanarella L (2016) Heavy metals in agricultural soils of the European Union with implications for food safety. Environ Int 88:299-309. https://doi.org/10.1016/j. envint.2015.12.017

UK GOV. National Statistics (2018) Agriculture in the United Kingdom. [Online] United Kingdom government; department for environment, food and rural affairs. https://assets.publishing.servi ce.gov.uk/government/uploads/system/uploads/attachment_data/ file/741062/AUK-2017-18sep18.pdf. Accessed 07 Dec 2018

Umweltbundesamt (1998) Umweltsurvey-Belastung der deutschen Wohnbevölkerung durch Umweltschadstoffe. Bundesgesundheitsblatt 3:118-124

Umweltbundesamt (2005) Neue und aktualisierte Referenzwerte für Schadstoffgehalte in Blut und Urin von Kindern-Arsen, Blei, Cadmium und Quecksilber. Bundesgesundheitsbl-Gesundheitsforsch -Gesundheitsschutz 48:1308-13012. https://doi. org/10.1007/s00103-005-1149-8

Umweltbundesamt (2009) Neue und aktualisierte Referenzwerte für Antimon, Arsen und Metalle (Blei, Cadmium, Nickel, Quecksilber, Thallium und Uran) im Urin und im Blut von Kindern in Deutschland. Bundesgesundheitsbl-GesundheitsforschGesundheitsschutz 59:77-82. https://doi.org/10.1007/s0010 3-009-0932-3
Vogel C, Exner RM, Adam C (2013) Heavy metal removal from sewage sludge ash by thermochemical treatment with polyvinylchloride. Environ Sci Technol 47:563-567. https://doi.org/10.1021/es200 7319

Waalkes MP, Diwan BA, Ward JM, Devor DE, Goyer RA (1995) Renal tubular tumors and atypical hyperplasias in $\mathrm{B} 6 \mathrm{C} 3 \mathrm{~F} 1$ mice exposed to lead acetate during gestation and lactation occur with minimal chronic nephropathy. Can Res 55:5265-5271

Wang G, Su M-Y, Chen Y-H, Lin F-F, Luo D, Gao SF (2006) Transfer characteristics of cadmium and lead from soil to edible parts of six vegetable species in southeastern China. Environ Poll 144:127135. https://doi.org/10.1016/j.envpol.2005.12.023

Wietlisbach V, Rickenbach M, Berode M, Guillemin M (1995) Time trend and determinants of blood lead levels in a Swiss population over a transition period (1984-1993) from leaded to unleaded gasoline. Environ Res 68(2):82-90. https://doi.org/10.1006/ enrs.1995.1011

WHO (2017) Guidelines for drinking water quality incorporating the first addendum, 4th edn. World Health Organization, Geneva

WHO/JEFCA (2011) Lead in: Safety evaluation of certain food additives and contaminants/prepared by the seventy-third meeting of the Joint FAO/WHO Expert Committee on Food Additives (JECFA). WHO Food Addit Ser 64:381-497

Publisher's Note Springer Nature remains neutral with regard to jurisdictional claims in published maps and institutional affiliations.

\section{Affiliations}

\section{Thomas Schupp $^{1}$ (1) Georg Damm ${ }^{2} \cdot$ Heidi Foth ${ }^{3} \cdot$ Alexius Freyberger $^{4} \cdot$ Thomas Gebel $^{5}$. Ursula Gundert-Remy ${ }^{6}$. Jan G. Hengstler ${ }^{7}$ Aswin Mangerich ${ }^{8} \cdot$ Falko Partosch $^{9} \cdot$ Claudia Röhl $^{10} \cdot$ Klaus-Michael Wollin $^{11}$}

\author{
Georg Damm \\ georg.damm@medizin.uni-leipzig.de \\ Heidi Foth \\ heidi.foth@uk-halle.de \\ Alexius Freyberger \\ alexius.freyberger@bayer.com \\ Thomas Gebel \\ gebel.thomas@baua.bund.de \\ Ursula Gundert-Remy \\ urusla.gundert-remy@charite.de \\ Jan G. Hengstler \\ hengstler@ifado.de \\ Aswin Mangerich \\ aswin.mangerich@uni-konstanz.de \\ Falko Partosch \\ falko.partosch@med.uni-goettingen.de \\ Claudia Röhl \\ claudia.roehl@lasd.landsh.de \\ Klaus-Michael Wollin \\ klaus-michael.wollin@t-online.de
}

1 Faculty of Chemical Engineering, Muenster University of Applied Science, Stegerwaldstrasse 39, 48565 Steinfurt, Germany
2 Department für Hepatobiliäre Chirurgie und Viszerale Transplantation, Universität Leipzig, Liebigstrasse 20, 04103 Leipzig, Germany

3 Institut für Umwelttoxikologie, Martin Luther Universität Halle, Franzosenweg 1, 06108 Halle (Saale), Germany

4 Pathology and Clinical Pathology, Bayer Aktiengesellschaft, Aprather Weg 18a, 421113 Wuppertal, Germany

5 Federal Institute for Occupational Safety and Health, Friedrich-Henkel-Weg 1-25, 44149 Dortmund, Germany

6 Charité, Institute of Clinical Pharmacology and Toxicology, Universitätsmedizin Berlin, Corporate Member of Freie Universität Berlin, Humboldt-Universität zu Berlin, Berlin Institute of Health, Berlin, Germany

7 Leibniz-Institut für Arbeitsforschung an der TU Dortmund (IfADo), Ardeystrasse 67, 44139 Dortmund, Germany

8 Molecular Toxicology Group, Department of Biology, University of Konstanz, Box 628, 78457 Konstanz, Germany

9 Institut für Arbeitsmedizin, Universitätsmedizin Göttingen, Waldweg 37b, 37073 Göttingen, Germany

10 Department of Environmental Health Protection, Schleswig-Holstein State Agency for Social Services, 24105 Kiel, Germany

11 Niedersächsisches Landesgesundheitsamt, 30449 Hannover, Germany 